\title{
A new cytotoxic indole-3-ethenamide from the halotolerant fungus Aspergillus sclerotiorum PT06-1
}

\author{
Hui Wang ${ }^{1,3}$, Jin-Kai Zheng ${ }^{1,3}$, Hai-Jun Qu ${ }^{2}$, Pei-Pei Liu ${ }^{1}$, Yi Wang ${ }^{1}$ and Wei-Ming Zhu ${ }^{1}$ \\ A new cytotoxic indole-3-ethenamide (1) and two known compounds, 7-(3-methylbut-2-enyl)-1 $H$-indole-3-carbaldehyde (2) and \\ emodin (3) were isolated and identified from the ethyl acetate extract of Aspergillus sclerotiorum PT06-1 in a hypersaline \\ nutrient-rich medium. On the basis of spectroscopic analysis and amino-acid analysis, the new structure of 1 was determined to \\ be $(S, E)$-3-methyl-2-( $N$ - methylacetamido)- $N$-(2-(7-(3-methylbut-2-enyl)-1H-indol-3-yl)vinyl)butanamide within 3:1 ratio of \\ rotamers along the acetamido single bond in DMSO- $d_{6}$ at room temperature. Compound 1 showed moderate cytotoxicity against \\ A-549 cells and weak cytotoxicity against HL-60 cells with the IC 50 values of 3.0 and $27 \mu \mathrm{M}$, respectively. Compound 2 has \\ been separated as natural product for the first time, and its NMR data were also reported for the first time in this study. \\ The Journal of Antibiotics (2011) 64, 679-681; doi:10.1038/ja.2011.63; published online 27 July 2011
}

Keywords: Aspergillus sclerotiorum; cytotoxicity; halotolerant fungus; indole-3-ethenamide

\begin{abstract}
INTRODUCTION
Natural products produced by halotolerant microorganisms have been considered as an important source of bioactive novel compounds, ${ }^{1-4}$ as hypersaline environment might activate some silent genes ${ }^{5}$ and induce unique biosynthesis pathways. ${ }^{6}$ Meanwhile, because of many of small peptides possessing a potential or an established use in cancer therapy, these compounds have intrigued us. ${ }^{7}$ Our previous work revealed two novel cyclic hexapeptides, ${ }^{8}$ and 11 new aspochracin-type cyclic tripeptides ${ }^{9}$ from the metabolites of marine-derived halotolerant fungus Aspergillus sclerotiorum PT06-1 in hypersaline nutrient-limited and nutrient-rich media, respectively. Further chemical study led to the identification of a new indole-3-ethenamide (1), along with two known compounds, 7-(3-methylbut-2-enyl)-1H-indole-3-carbaldehyde $(2)^{10}$ and emodin $(3)^{11}$ from the ethyl acetate extract of the fermentation broth of A. sclerotiorum PT06-1 in a hypersaline nutrient-rich medium. New compound 1 displayed cytotoxicity against A-549 and HL-60 cell lines with IC $_{50}$ values of 3.0 and $27 \mu \mathrm{M}$, respectively. NMR Data of 2, isolated from the natural source for the first time, was also reported in this study for lack of the corresponding data in literature.
\end{abstract}

\section{RESULTS}

Physico-chemical properties

Compound 1: yellow amorphous powder; $[\alpha]_{\mathrm{D}}^{25}-67.5\left(c 0.3, \mathrm{CH}_{3} \mathrm{OH}\right)$; HR-ESI-MS $m / z \quad 382.2490[\mathrm{M}+\mathrm{H}]^{+}$(calcd for $\mathrm{C}_{23} \mathrm{H}_{32} \mathrm{~N}_{3} \mathrm{O}_{2}$, 382.2495); UV $\left(\mathrm{CH}_{3} \mathrm{OH}\right) \lambda_{\max }(\log \varepsilon) \mathrm{nm} 202$ (4.67), 224 (4.56),
292 (4.43); IR $v_{\max } \mathrm{cm}^{-1}(\mathrm{KBr}) 3388,3279,2969,2930,1689,1633$, 1532, 1447, 1324, 1226, 1060, 961, $779 \mathrm{~cm}^{-1}$. ${ }^{1} \mathrm{H}$ and ${ }^{13} \mathrm{C}$ NMR (see Table 1).

Compound 2: yellow amorphous powder; ${ }^{1} \mathrm{H}$ NMR $\left(\mathrm{CDCl}_{3}\right.$, $600 \mathrm{MHz}) \delta_{\mathrm{H}} 12.16(1 \mathrm{H}$, br s, H-1), $9.94(1 \mathrm{H}, \mathrm{s}, 3-\mathrm{CHO}), 8.29(1 \mathrm{H}$, d, $J=2.2 \mathrm{~Hz}, \mathrm{H}-2), 7.93(1 \mathrm{H}, \mathrm{d}, J=7.3 \mathrm{~Hz}, \mathrm{H}-4), 7.15$ (1H, 't' like, $J=7.3,7.0 \mathrm{~Hz}, \mathrm{H}-5), 7.03(1 \mathrm{H}, \mathrm{d}, J=7.0 \mathrm{~Hz}, \mathrm{H}-6), 5.41(1 \mathrm{H}, \mathrm{tt}, J=7.3$, $\left.1.5 \mathrm{~Hz}, \mathrm{H}-2^{\prime}\right), 3.58\left(2 \mathrm{H}, \mathrm{d}, J=7.3 \mathrm{~Hz}, \mathrm{H}-1^{\prime}\right), 1.73\left(6 \mathrm{H}, \mathrm{s}, \mathrm{H}-4^{\prime} / 5^{\prime}\right) ;{ }^{13} \mathrm{C}$ NMR $\left(\mathrm{CDCl}_{3}, 150 \mathrm{MHz}\right) \delta_{\mathrm{C}} 185.0(\mathrm{~d}, 3-\mathrm{CHO}), 138.3$ (d, C-2), 135.8 (s, C-7a), 132.6 (s, C-3'), 125.6 (s, C-3a), 124.2 (s, C-7), 122.6 (d, C-5), 122.4 (d, C-6), 121.8 (d, C-2'), 118.6 (s, C-3), 118.5 (d, C-4), 28.9 (t, C-1'), 25.5 (q, C-4'), 17.8 (q, C-5').

\section{Cytotoxicity}

The cytotoxicity of 1 was evaluated against A-549 cell line by the SRB method and HL-60 cell line by the MTT method, with the IC $_{50}$ values of $3.0 \mu \mathrm{M}$ and $27 \mu \mathrm{M}$, respectively.

\section{Structure determination}

Compound 1, obtained as single peak during HPLC separation, was isolated as yellow amorphous powder. The molecular formula of $\mathbf{1}$ was determined to be $\mathrm{C}_{23} \mathrm{H}_{31} \mathrm{~N}_{3} \mathrm{O}_{2}$ from the positive HRESIMS peak at $m / z 382.2490[\mathrm{M}+\mathrm{H}]^{+}$(cacld for $\mathrm{C}_{23} \mathrm{H}_{32} \mathrm{~N}_{3} \mathrm{O}_{2}, 382.2495$ ). UV absorptions at $\lambda_{\max }$ at 202, 224 and $292 \mathrm{~nm}$ indicated an aromatic chromophore or extended conjugation. Broad IR absorptions at 3279 and $1633 \mathrm{~cm}^{-1}$ indicated the presence of amide $\mathrm{NH}$ and an amide

\footnotetext{
${ }^{1}$ Key Laboratory of Marine Drugs, Chinese Ministry of Education, Institute of Marine Drugs and Food, Ocean University of China, Qingdao, PR China and ${ }^{2}$ Affiliated Hospital of Medical College, Qingdao University, Qingdao, PR China

${ }^{3}$ These authors contributed equally to this work.

Correspondence: Dr W-M Zhu, Key Laboratory of Marine Drugs, Chinese Ministry of Education, School of Medicine and Pharmacy, Institute of Marine Drugs and Food, Ocean University of China, Qingdao, Shandong 266003 China.

E-mail: weimingzhu@ouc.edu.cn

Received 17 April 2011; revised 20 June 2011; accepted 22 June 2011; published online 27 July 2011
} 
carbonyl, respectively. The NMR data for $\mathbf{1}$, however, were much more complex than expected. Interestingly, two sets of NMR signals appeared, with the ratio of 3:1 in DMSO- $d_{6}$ at room temperature. The ${ }^{1} \mathrm{H}$ and ${ }^{13} \mathrm{C}$ NMR spectra (Supplementary Figures S2 and S3) of the major one (1a) displayed characteristic signals for one indole and one isopentenyl moiety. ${ }^{1} \mathrm{H}-{ }^{1} \mathrm{H}$ COSY (Supplementary Figure S6) of $\mathrm{HN}-1 / \mathrm{H}-2, \mathrm{H}-4 / \mathrm{H}-5 / \mathrm{H}-6$ and $\mathrm{H}-8 / \mathrm{H}-9 / \mathrm{HN}-10$, and the key HMBC (Supplementary Figure S7) correlations from H-1' $\left(\delta_{\mathrm{H}} 3.52\right)$ to C-6 $\left(\delta_{\mathrm{C}} 120.7\right), \mathrm{C}-7\left(\delta_{\mathrm{C}} 125.0\right), \mathrm{C}-7 \mathrm{a}\left(\delta_{\mathrm{C}} 135.7\right)$ and C-3' $\left(\delta_{\mathrm{C}} 132.3\right)$, from $\mathrm{H}-8\left(\delta_{\mathrm{H}} 6.44\right)$ to $\mathrm{C}-2\left(\delta_{\mathrm{C}} 123.5\right)$ and $\mathrm{C}-3 \mathrm{a}\left(\delta_{\mathrm{C}} 125.0\right)$ and from $\mathrm{H}-4^{\prime} /$ $\mathrm{H}-5^{\prime}\left(\delta_{\mathrm{H}} 1.71\right)$ to $\mathrm{C}-2^{\prime}\left(\delta_{\mathrm{C}} 122.3\right)$, and $\mathrm{C}-3^{\prime}$ further supported that a 7-isopentenylindol-3-(2-aminoethenyl) indole moiety was presented in 1a. The large coupling constant, $J_{8,9}(15.1 \mathrm{~Hz})$ indicated $E$ - config-

Table $1{ }^{1} \mathrm{H}$ and ${ }^{13} \mathrm{C}$ NMR (600 and $150 \mathrm{MHz}$ ) data for compound 1 $(1 \mathrm{a} \text { and } 1 \mathrm{~b})^{\mathrm{a}}$

\begin{tabular}{|c|c|c|c|c|}
\hline \multirow[b]{2}{*}{ Position } & \multicolumn{2}{|l|}{$1 a$} & \multicolumn{2}{|l|}{$1 b$} \\
\hline & $\delta_{H}(\mathrm{~J}$ in $\mathrm{Hz})$ & $\delta_{C}$ & $\delta_{H}(\mathrm{~J}$ in $\mathrm{Hz})$ & $\delta_{C}$ \\
\hline $1-\mathrm{NH}$ & $11.08(1 \mathrm{H}, \mathrm{br} \mathrm{s})$ & - & $11.12(1 \mathrm{H}, \mathrm{br} \mathrm{s})$ & - \\
\hline 2 & $7.41(1 \mathrm{H}, \mathrm{d}, 2.8)$ & $123.5 \mathrm{~d}$ & $7.46(1 \mathrm{H}, \mathrm{d}, 2.3)$ & $123.7 \mathrm{~d}$ \\
\hline 3 & - & $112.2 \mathrm{~s}$ & - & $112.2 \mathrm{~s}$ \\
\hline 3a & - & $125.0 \mathrm{~s}$ & - & $125.0 \mathrm{~s}$ \\
\hline 4 & $7.45(1 \mathrm{H}, \mathrm{d}, 7.8)$ & $116.8 \mathrm{~d}$ & $7.47(1 \mathrm{H}, \mathrm{d}, 7.8)$ & $116.8 \mathrm{~d}$ \\
\hline 5 & $6.99(1 \mathrm{H}, \mathrm{t}, 7.8)$ & $119.7 \mathrm{~d}$ & $6.99(1 \mathrm{H}, \mathrm{t}, 7.8)$ & $119.8 \mathrm{~d}$ \\
\hline 6 & $6.89(1 \mathrm{H}, \mathrm{d}, 7.3)$ & $120.7 \mathrm{~d}$ & 6.90 (overlay) & $120.7 \mathrm{~d}$ \\
\hline 7 & - & $125.0 \mathrm{~s}$ & - & $125.0 \mathrm{~s}$ \\
\hline $7 a$ & - & $135.7 \mathrm{~s}$ & - & $135.7 \mathrm{~s}$ \\
\hline 8 & $6.44(1 \mathrm{H}, \mathrm{d}, 15.1)$ & $107.4 \mathrm{~d}$ & $6.48(1 \mathrm{H}, \mathrm{d}, 15.1)$ & $107.8 \mathrm{~d}$ \\
\hline 9 & $7.27(1 \mathrm{H}, \mathrm{dd}, 15.1,10.1)$ & $119.4 \mathrm{~d}$ & $7.30(1 \mathrm{H}, \mathrm{dd}, 15.1,10.1)$ & $119.2 \mathrm{~d}$ \\
\hline $10-\mathrm{NH}$ & $10.16(1 \mathrm{H}, \mathrm{d}, 10.1)$ & - & $10.26(1 \mathrm{H}, \mathrm{d}, 10.1)$ & - \\
\hline 11 & - & $167.4 \mathrm{~s}$ & - & $166.7 \mathrm{~s}$ \\
\hline 12 & $4.71(1 \mathrm{H}, \mathrm{d}, 11.0)$ & $60.9 d$ & $3.88(1 \mathrm{H}, \mathrm{d}, 10.6)$ & $66.3 d$ \\
\hline 14 & - & $170.9 \mathrm{~s}$ & - & $170.3 \mathrm{~s}$ \\
\hline 15 & $2.06(3 \mathrm{H}, \mathrm{s})$ & $22.2 \mathrm{q}$ & $2.16(3 \mathrm{H}, \mathrm{s})$ & $22.3 \mathrm{q}$ \\
\hline 16 & $2.16(1 \mathrm{H}, \mathrm{m})$ & $26.9 \mathrm{~d}$ & $2.25(1 \mathrm{H}, \mathrm{m})$ & $27.4 \mathrm{~d}$ \\
\hline 17 & $0.90(3 \mathrm{H}, \mathrm{d}, 6.4)$ & $19.5 \mathrm{q}$ & $0.92(3 \mathrm{H}, \mathrm{d}, 6.4)$ & $19.4 \mathrm{q}$ \\
\hline 18 & $0.79(3 \mathrm{H}, \mathrm{d}, 6.9)$ & $19.0 \mathrm{q}$ & $0.84(3 \mathrm{H}, \mathrm{d}, 6.4)$ & $18.7 \mathrm{q}$ \\
\hline 19 & $3.00(3 \mathrm{H}, \mathrm{s})$ & $31.4 \mathrm{q}$ & $2.82(3 \mathrm{H}, \mathrm{s})$ & $28.4 \mathrm{q}$ \\
\hline $1^{\prime}$ & $3.52(2 \mathrm{H}, \mathrm{d}, 6.9)$ & $29.1 \mathrm{t}$ & $3.52(2 \mathrm{H}, \mathrm{d}, 6.9)$ & $29.1 \mathrm{t}$ \\
\hline $2^{\prime}$ & $5.42(1 \mathrm{H}, \mathrm{t}, 6.6)$ & $122.3 \mathrm{~d}$ & $5.42(1 \mathrm{H}, \mathrm{t}, 6.6)$ & $122.3 \mathrm{~d}$ \\
\hline $3^{\prime}$ & - & $132.3 \mathrm{~s}$ & - & $132.3 \mathrm{~s}$ \\
\hline $4^{\prime}$ & $1.71(3 \mathrm{H}, \mathrm{s})$ & $25.7 \mathrm{q}$ & $1.71(3 \mathrm{H}, \mathrm{s})$ & $25.7 \mathrm{q}$ \\
\hline $5^{\prime}$ & $1.71(3 \mathrm{H}, \mathrm{s})$ & $17.9 \mathrm{q}$ & $1.71(3 \mathrm{H}, \mathrm{s})$ & $17.9 q$ \\
\hline
\end{tabular}

aThe assignments were based on DEPT, HMQC, ${ }^{1} \mathrm{H}^{1}{ }^{1} \mathrm{H}$ COSY and HMBC experiments, and recorded in DMSO- $d_{6}$ using TMS as internal standard. uration of the $\mathrm{C}_{8}=\mathrm{C}_{9}$ double bond. In addition, ${ }^{1} \mathrm{H}-{ }^{1} \mathrm{H}$ COSY of $\mathrm{H}-12 / \mathrm{H}-16 / \mathrm{H}-17$ and $\mathrm{H}-16 / \mathrm{H}-18$ and HMBC connections from $\mathrm{H}-12$ $\left(\delta_{\mathrm{H}} 4.71\right)$ to $\mathrm{C}-11\left(\delta_{\mathrm{C}} 167.4\right)$ and $\mathrm{C}-14\left(\delta_{\mathrm{C}} 170.9\right)$, from $\mathrm{H}-19\left(\delta_{\mathrm{H}}\right.$ $3.00)$ to $\mathrm{C}-12\left(\delta_{\mathrm{C}} 60.9\right)$ and $\mathrm{C}-14$, and from $\mathrm{H}-15\left(\delta_{\mathrm{H}} 2.06\right)$ to $\mathrm{C}-14$ suggested that a $N$-acetyl- $N$-methylvaline unit was also presented in 1a (Figure 1). The key HMBC correlation between HN-10 $\left(\delta_{\mathrm{H}} 10.16\right)$ and C-11 revealed that the two moieties were further connected into amide. The minor one (1b) shared the same 2D NMR correlations as those of 1a (Supplementary Figure S5-S8). The obvious differences of ${ }^{1} \mathrm{H}$ and ${ }^{13} \mathrm{C}$ NMR between $\mathbf{1 a}$ and $\mathbf{1 b}$ main were $\delta_{\mathrm{CH}-12}, \delta_{\mathrm{CH}-19}$ and $\delta_{\mathrm{H}-15}$ (Table 1), indicating that $\mathbf{1 a}$ and $\mathbf{1 b}$ was a pair of conformers resulted from the rotation of acetamido single bond, $\mathrm{N}_{13} \mathrm{C}_{14}$. The synperiplanar ( $s p$ )/antiperiplanar (ap) interconversion of amide rotamers is sufficiently slow on the NMR spectroscopy that display steric and electronic differences. ${ }^{12}$ The $s p$ and $a p$ configurations of $\mathbf{1 a}$ and $\mathbf{1 b}$, respectively, were deduced from the upfield shift for $\mathrm{CH}-12$ in $\mathbf{1 a}$ and $\mathrm{CH}_{3}-19$ in $\mathbf{1 b}$, respectively, due to the shielding effect of $14-\mathrm{CO}{ }^{13}$ This deduction was further supported by the NOE effects between $\mathrm{H}-15$ and $\mathrm{H}-19$ in 1a, and between $\mathrm{H}-15$ and $\mathrm{H}-12$ in 1b, respectively, in NOESY experiment (Figure 1 and Supplementary Figure S8). The absolute configuration of $N$-methylvaline unit was determined as L- by Marfey's method. ${ }^{14}$ The FDAA derivatives of the acid hydrolysates of $\mathbf{1}$ gave the same retention time as that prepared from authentic $N$-Me-L-Val in HPLC analysis (Supplementary Figure S1). Thus, structure of 1 was determined to be $(S, E)-3-$ methyl-2-(Nmethylacetamido)- $\mathrm{N}$-(2-(7-(3-methylbut-2-enyl)-1H-indol-3-yl)vinyl) butanamide. To the best of our knowledge, dipeptides possessing dehydrotryptamine functionality were scarcely found in nature.

\section{Biosynthesis}

Compound 1 was probably biosynthesized mainly via a mixed aminoacid mevalonic-acid pathway. Tryptophan and valine condensed to a dipeptide that then underwent decarboxylation, dehydrogenation and isoprenylation with mevalonic acid to form an intermediate 1c. The intermediate $1 \mathrm{c}$ was postulated to further undergo $\mathrm{N}$-acylation

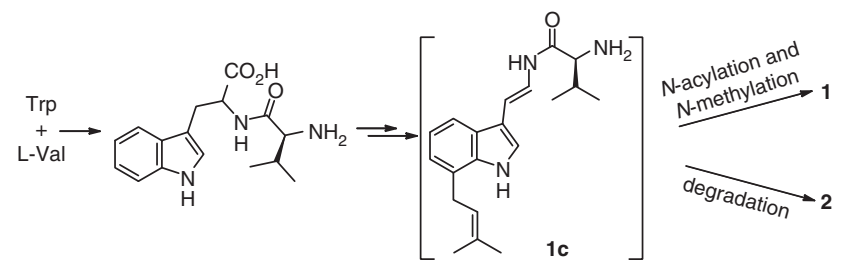

Scheme 1 The postulated biosynthesis of 1 and 2 .

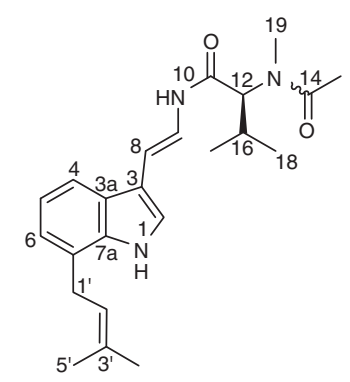

$\mathbf{1}(\mathbf{a}: s p-, \mathbf{b}: a p-, \mathbf{a}: \mathbf{b}$ 3:1)<smiles>CC(C)=CCc1cccc2c(C=O)c[nH]c12</smiles><smiles>Cc1cc(O)c2c(c1)C(=O)c1cc(O)cc(O)c1C2=O</smiles>

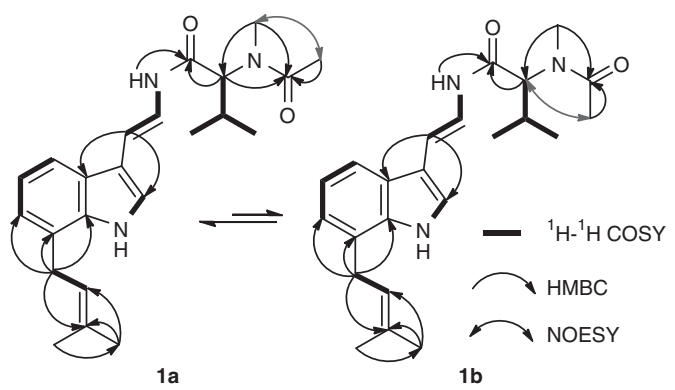

$1 a$

Figure 1 Structures of $1-3$ and the key ${ }^{1} \mathrm{H}_{-}{ }^{1} \mathrm{H}$ COSY, HMBC and NOESY correlations of $\mathbf{1}$ (a and $\mathbf{b}$ ). A full color version of this figure is available at The Journal of Antibiotics journal online. 
and $\mathrm{N}$-methylation to produce the bioactive 1 . Compound 2 might be resulted from the degradation of intermediate 1c (Scheme 1).

\section{METHODS}

\section{General experimental procedures}

Optical rotations were obtained on a JASCO P-1020 digital polarimeter (JASCO Corporation, Tokyo, Japan). IR spectra were recorded using a Bruker model. UV spectra were recorded on Beckman DU 640 spectrophotometer (Beckman, Brea, CA, USA). ${ }^{1} \mathrm{H},{ }^{13} \mathrm{C}$ NMR and DEPT spectra and 2D-NMR were recorded on a JEOL JNM-ECP 600 spectrometer (JEOL Ltd., Tokyo, Japan) using TMS as internal standard and chemical shifts were recorded as $\delta$ values. ESI-MS was measured on a Q-TOF Ultima Global GAA076 LC mass spectrometer (Waters, Milford, MA, USA). Semipreparative HPLC was performed using an ODS column (YMC-pack ODS-A, $10 \times 250 \mathrm{~mm}, 5 \mu \mathrm{M}, 4 \mathrm{ml} \mathrm{min}^{-1}$ ).

\section{Strain}

The halotolerant fungus A. sclerotiorum PT06-1 was isolated from sediments collected in the Putian salt field, Fujian Province of China. It was identified according to its morphological characteristics and $18 \mathrm{~S}$ rRNA sequences. ${ }^{8,9}$ The voucher specimen is deposited in our laboratory at $-80^{\circ} \mathrm{C}$. The working strain was prepared on potato dextrose agar slants containing $10 \% \mathrm{NaCl}$ and stored at $4{ }^{\circ} \mathrm{C}$

\section{Fermentation}

The fungus A. sclerotiorum PT06-1 was incubated on a rotary shaker (160 rpm) at $28^{\circ} \mathrm{C}$ for 16 days in $500 \mathrm{ml} \times 200$ conical flasks containing the liquid medium ( $150 \mathrm{ml}$ per flask) composed of glucose (1.5 g), maltose ( $3 \mathrm{~g})$, mannitol (3g), yeast extract $(0.45 \mathrm{~g})$, monosodium glutamate $(1.5 \mathrm{~g})$, corn steep liquor $(0.15 \mathrm{~g}), \mathrm{NaCl}(12 \mathrm{~g}), \mathrm{MgSO}_{4}(0.75 \mathrm{~g}), \mathrm{KH}_{2} \mathrm{PO}_{4}(0.75 \mathrm{~g}), \mathrm{NH}_{4} \mathrm{Cl}(0.75 \mathrm{~g})$ and $\mathrm{KCl}(0.75 \mathrm{~g})$, adjusting its $\mathrm{pH}$ to 7.0 .

\section{Extraction and isolation}

The fermented whole broth (301) was filtered through cheesecloth to separate into supernatant and mycelia. The former was concentrated in vacuo to about a quarter of original volume and then extracted three times with the same volume of ethyl acetate to give an ethyl acetate solution, while the latter was extracted three times with 51 acetone- $\mathrm{H}_{2} \mathrm{O}$ (4:1). The acetone solution was evaporated under reduced pressure to afford an aqueous solution. The aqueous solution was extracted three times with the same volume of ethyl acetate to give another ethyl acetate solution. Both the ethyl acetate solutions were combined and concentrated in vacuo to give a crude extract $(50.2 \mathrm{~g})$. The crude extract was then subjected to vacuum liquid chromatography using step gradient elution with $\mathrm{CHCl}_{3}-\mathrm{MeOH}(100: 0,100: 1,50: 1,30: 1,20: 1,10: 1)$ to give six fractions (fractions 16) based on TLC properties. Fraction 3 (7g) eluted with $\mathrm{CHCl}_{3}-\mathrm{MeOH}$ (50:1) was further applied to ODS column chromatography using step gradient elution with $\mathrm{H}_{2} \mathrm{O}-\mathrm{MeOH}$ into five subfractions (fractions 3.13.5). The subfraction $3.4\left(480 \mathrm{mg}\right.$ ), eluted with $\mathrm{MeOH}-\mathrm{H}_{2} \mathrm{O}(4: 1)$, was then separated by semipreparative HPLC $\left(80 \% \mathrm{MeOH}-\mathrm{H}_{2} \mathrm{O}\right)$ to yield $3\left(10 \mathrm{mg}, t_{\mathrm{R}}\right.$ $5 \mathrm{~min}), 2\left(3 \mathrm{mg}, t_{\mathrm{R}} 10 \mathrm{~min}\right)$ and $1\left(8 \mathrm{mg}, t_{\mathrm{R}} 16 \mathrm{~min}\right)$.

\section{Absolute configuration of amino acid in 1 by Marfey's method}

Compound $1(1 \mathrm{mg})$ was hydrolyzed in $\mathrm{HCl}(6 \mathrm{M} ; 1 \mathrm{ml})$ for $20 \mathrm{~h}$ at $110^{\circ} \mathrm{C}^{14}$ The solution was then evaporated to dryness and redissolved in $\mathrm{H}_{2} \mathrm{O}(250 \mu \mathrm{l})$. A $100 \mu \mathrm{l}$ of $1 \%(\mathrm{w} / \mathrm{v})$ solution of L-FDAA (1-fluoro-2,4-dinitrophenyl-5-Lalanine amide) in acetone was then added to an aliquot $(50 \mu \mathrm{l})$ of the acid hydrolysate solution. After addition of $\mathrm{NaHCO}_{3}$ solution (1M; $20 \mu \mathrm{l}$ ), the mixture was incubated at $45^{\circ} \mathrm{C}$ for $1 \mathrm{~h}$. The reaction was quenched by addition of $\mathrm{HCl}(2 \mathrm{M}, 10 \mu \mathrm{l})$. Analyses of the FDAA derivatized hydrolysate of 1 and standard FDAA-derivatized $N$-Me-Val were carried out by HPLC (solvents: A water $+0.2 \% \mathrm{TFA}, \mathrm{B}$ MeCN; linear gradient: 0 min $25 \%$ B, $40 \mathrm{~min} 60 \%$ B, 45 min $100 \% \mathrm{~B} ; 30^{\circ} \mathrm{C} 1 \mathrm{ml} \mathrm{min}^{-1}$; UV detection at $\lambda 340 \mathrm{~nm}$ ). Retention times for the $\mathrm{N}$-Me-valine ( $\mathrm{N}$-Me-Val) derivatives of hydrolysates of 1 and the authentic $N$ Me-L-Val and N-Me-D-Val were $t_{\mathrm{R}} 28.3 \mathrm{~min}, 28.4 \mathrm{~min}$ and $30.8 \mathrm{~min}$, respec- tively. Co-injection of the authentic sample with the hydrolysate confirmed that the $\mathrm{N}$-Me-Val residue was L-configuration (Supplementary Figure S1).

\section{Biological assay}

Compounds 1 was evaluated for cytotoxic effects on HL-60 cell line using the MTT method ${ }^{15}$ and on A-549 cell line using the SRB method. ${ }^{16}$ In the MTT assay, cell lines were grown in RPMI-1640 supplemented with $10 \%$ FBS under a humidified atmosphere of $5 \% \mathrm{CO}_{2}$ and $95 \%$ air at $37^{\circ} \mathrm{C}$. Cell suspensions, $200 \mu \mathrm{l}$, at a density of $5 \times 10^{4}$ cell per $\mathrm{ml}$ were plated in 96-well microtiter plates and incubated for $24 \mathrm{~h}$. Thereafter, $2 \mu \mathrm{l}$ of the test solutions (in $\mathrm{MeOH}$ ) were added to each well and further incubated for $72 \mathrm{~h}$. The MTT solution $(20 \mu \mathrm{l}$, $5 \mathrm{mg} \mathrm{ml}^{-1}$ in IPMI-1640 medium) was then added to each well and incubated for $4 \mathrm{~h}$. Old medium containing MTT $(150 \mu \mathrm{l})$ was then gently replaced by DMSO and pipetted to dissolve any formazan crystals formed. Absorbance was then determined on a Spectra Max Plus plate reader (Molecular Devices, Sunnyvale, CA, USA) at $540 \mathrm{~nm}$. In the SRB assay, $200 \mu \mathrm{l}$ of the cell suspensions were plated in 96-well plates at a density of $2 \times 10^{5}$ cell per ml. Thereafter, $2 \mu \mathrm{l}$ of the test solutions (in $\mathrm{MeOH}$ ) was added to each well and the culture was further incubated for $24 \mathrm{~h}$. The cells were fixed with $12 \%$ trichloroacetic acid and the cell layer stained with $0.4 \%$ SRB. The absorbance of the SRB solution was measured at $515 \mathrm{~nm}$. The $\mathrm{IC}_{50}$ values were obtained using the Bliss method.

\section{ACKNOWLEDGEMENTS}

This work was supported by grants from the Major Program for Technique Development Research of New Drugs in China (No. 2009ZX09103-046), from Special Fund for Marine Scientific Research in the Public Interest of China (No. 2010418022-3), from National Basic Research Program of China (No. 2010CB833800), from the National Natural Science Foundation of China (No. 30470196 \& 30670219), and from PCSIRT (No. IRT0944). The cytotoxicity assay was performed at the Shanghai Institute of Materia Medica, Chinese Academy of Sciences.

1 Lu, Z. Y. et al. Citrinin dimers from the halotolerant fungus Penicillium citrinum B-57. J. Nat. Prod. 71, 543-546 (2008).

2 Wang, W. L. et al. Two new cytotoxic quinone type compounds from the halotolerant fungus Aspergillus variecolor. J. Antibiot. 60, 603-607 (2007).

3 Wang, W. L. et al. Isoechinulin-type alkaloids, variecolorin A-L, from halotolerant Aspergillus variecolor. J. Nat. Prod. 70, 1558-1564 (2007).

4 Wang, W. L. et al. Three novel, structurally unique spirocyclic alkaloids from the halotolerant B-17 fungus strain of Aspergillus variecolor. Chem. Biodiv. 4, 2913-2919 (2007).

5 Koch, A.L. Genetic response of microbes to extreme challenges. J. Theor. Biol. 160, 1-21 (1993).

6 Méjanelle, L., Lòpez, J. F., Gunde-Cimerman, N. \& Grimalt, J. O. Ergosterol biosynthesis in novel melanized fungi from hypersaline environments. J. Lipid. Res. 42, 352-358 (2001).

7 Janin, Y. L. Peptides with anticancer use or potential. Amino Acids 25, 1-40 (2003).

8 Zheng, J. K. et al. Novel cyclic hexapeptides from marine-derived fungus, Aspergillus sclerotiorum PT06-1. Org. Lett. 11, 5262-5265 (2009).

9 Zheng, J. K. et al. Cyclic tripeptides from the halotolerant fungus Aspergillus sclerotiorum PT06-1. J. Nat. Prod. 73, 1133-1137 (2010).

10 Liu, K., Wood, H. B. \& Jones, A. B. Total synthesis of asterriquinone B-1. Tetrahedron Lett. 40, 5119-5122 (1999).

11 Cohen, P. A. \& Towers, G. H. N. Anthraquinones and Phenanthroperylenequinones from Nephroma Laevigatum. J. Nat. Prod. 58, 520-526 (1995).

12 Dugave, C. \& Demange, L. CisTrans isomerization of organic molecules and biomolecules: implications and applications. Chem. Rev. 103, 2475-2532 (2003).

13 Toske, S. G., Jensen, P. R., Kauffman, C. A. \& Fenical, W. Aspergillamides A and B: modified cytotoxic tripeptides produced by a marine fungus of the genus Aspergillus. Tetrahedron 54, 13459-13466 (1998).

14 Marfey, P. Determination of D-amino acids. II. Use of a bifunctional reagent, 1,5difluoro-2,4dinitrobenzene. Carlsberg Res. Commun. 49, 591-596 (1984)

15 Mosmann, T. Rapid colorimetric assay for cellular growth and survival: application to proliferation and cytotoxicity assays. J. Immunol. Meth. 65, 55-63 (1983).

16 Skehan, P. et al. New colorimetric cytotoxicity assay for anticancer drug screening. J. Nat. Cancer Inst. 82, 1107-1112 (1990). 